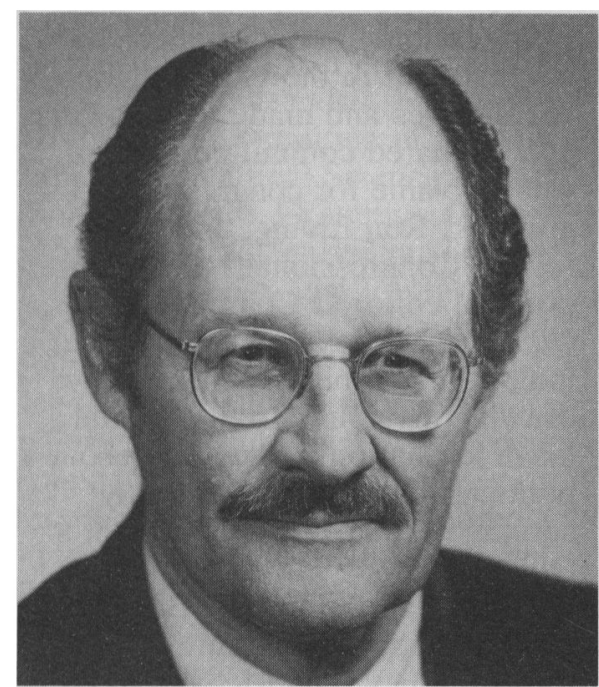

Charles O. Jones

APSA recently participated in a month-long Distance Learning Project to Moscow using a television/satellite link. Under the direction of Deputy Director Robert Hauck, a program entitled "Current Approaches to Political Science" was developed to discuss issues in American democracy and government. In six pilot programs that aired over the month of May, leading scholars in the discipline, including two former APSA Presidents and the current President, Charles $\mathrm{O}$. Jones, lectured in "real time" over satellite to a classroom of Russian upper-level and graduate students and faculty.

Each 90-minute program, moderated by Catherine Rudder of the APSA, covered a major subfield of

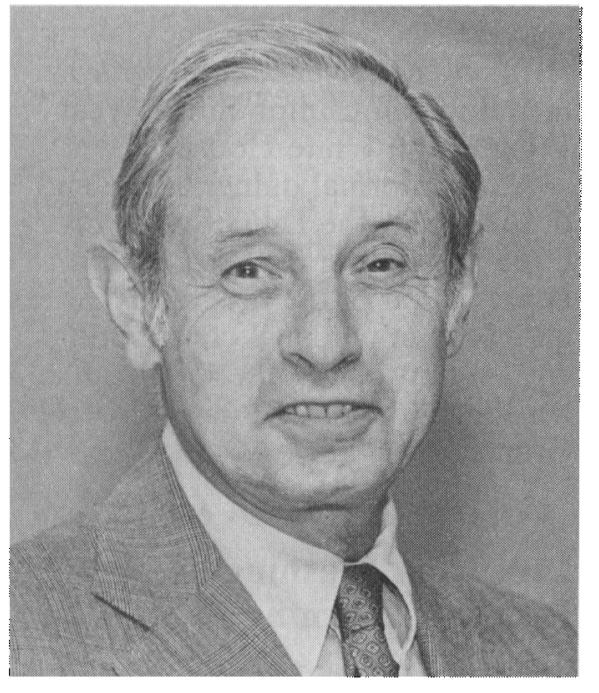

Leon Epstein the discipline. The presenter, along with the moderator, sought to identify key aspects in the development of democracy and political science in the United States. Paul Weber, a constitutional scholar from the University of Louisville, opened the series with an in-depth look into the roles of constitutions in democracy. APSA President Jones of the University of Wisconsin-Madison and currently at The Brookings Institution, addressed the relationship between the executive and legislative branches and the issues of checks and balances. Leon Epstein, professor emeritus at the University of Wisconsin-Madison, focused on political parties, political participation, and elections.

Samuel Beer, professor emeritus at Harvard University, and Marian Palley from the University of Delaware, discussed the issue of civic federalism and the role of contemporary intergovernmental relationships. George Quester, of the University of Maryland at College Park, analyzed the future vital interests of the United States in a discussion on Foreign Affairs and the Global Political Economy. The program concluded with Francis Rourke of Johns Hopkins University and Christopher Foreman of The Brookings Institution discussing the role of the bureaucracy in the implementation of public policy.

The group in Moscow included students from 13 different institutions and a number of junior faculty. Anne Mavity of the National Democratic Institute served as moderator and facilitator on the Moscow end. Students participating included representatives from Moscow State University, the Russian State University for the Humanities, the International University, Moscow State Institute of International Affairs, Ryazan State University, the Laboratory of Gender Studies and the Moscow Pedagogical University. Initial warnings from experienced Russian insiders that the students would not be active in asking questions proved false as the students and faculty bombarded the presenters with both historical and theoretical questions. The students displayed an impressive knowledge of American

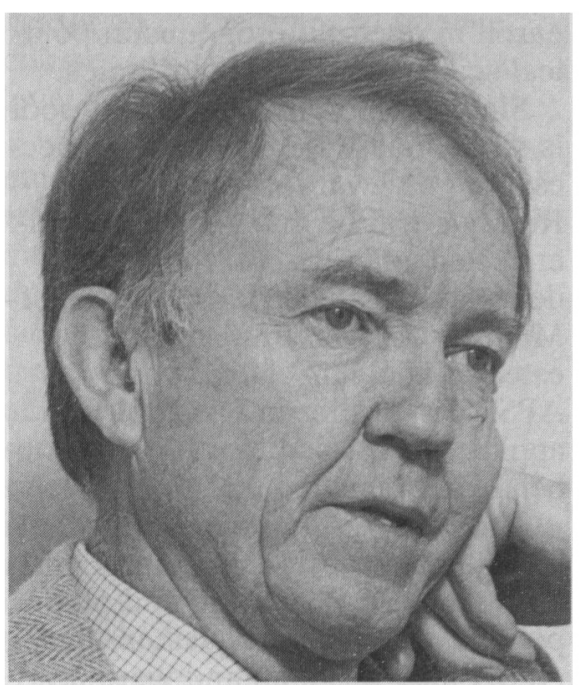

Francis Rourke

politics and history in their questions and demonstrated a strong interest in dissecting the inner workings of the American political system.

The combination of interactive video technology and the active participation of the students in Moscow made for the true interactive learning project that all groups intended. Under the direction of Rudder and Mavity the students were able to ask questions throughout each lecture and at times planned lectures were rerouted to address the multitude of questions thrown out by the students.

The program was a tremendous success and the Committee on International Programs will be looking to applying the technology in new ways and areas of the world. Discussions are underway with USIA on how to build on the pilot program and extend its scope to other Newly Independent States of the former Soviet Union.

\section{The American Political Science Association Gopher Server Up and Running}

The American Political Science Association Gopher Server is now available on the internet. To connect to it simple point your gopher client to apsa.trenton.edu. If you are unfamiliar with using gopher servers contact your local computing help service.

The purpose of the APSA gopher 
is to provide access to online resources useful for political science research and teaching. It is largely an umbrella gopher, providing links to other gopher servers where the documents are actually maintained. Documents maintained at the site of the APSA gopher server will include those of general interest to the discipline (e.g., conference programs) or those which are not accessible elsewhere.

The current main menu of the APSA gopher server is as follows:
About the American Political Science Association Gopher
American Government Gopher at Northwestern University
Comparative Politics
International Relations
Political Theory
Computers, Software, \& Data
The Political Science List of Lists
Conference Information
Scholarships and Fellowships
Related Gophers and Reference Information

The APSA gopher server is still in the developmental stage-expect new items and updated documents in the near future. It has nevertheless already become quite popular as a political science resource and is averaging over 100 log-ins per day.

The APSA gopher server is designed to work in conjunction with the Political Science Research and Teaching List (psrt-1) which itself has 1100 subscribers in 34 countries. PSRT-L is a Listserv discussion group (send the command "subscribe psrt-l your name" to listserv@missou1.missouri.edu to join).

Remember, as you explore the menu items in the APSA gopher, that you may be viewing menus and accessing documents stored anywhere in the world. Please direct your feedback on the contents of individual items on the gopher to the appropriate site. Inquiries relevant to political science research and teaching as well as short announcements and abstracts of other documents should be sent to the list (psrt-1@missou1.missouri.edu) for distribution to other participants. Long documents and any archival material (examples include conference programs, writing of more than a few paragraphs, data, reference material, etc) should be placed on the APSA gopher.

We are looking for new materials for the APSA gopher. In particular we would like to list conference announcements, calls for papers, and the like on the gopher, as well as to link to other relevant gophers. Bill Ball is the general coordinator of the APSA gopher project. Please contact him with general questions and comments at ball@trenton.edu or (609) 771-2747; or contact Michael Brintnall at APSA at incem024@sivm.si.edu or (202) 483-2512. If you know of resources that should be considered for the gopher, or wish to volunteer to assist in its management, please also contact Bill Ball or Michael Brintnall.

\section{Research Support Grants Announced}

The APSA Research Support Committee recently made 13 awards totaling $\$ 15,000$ under APSA's program to support research by political scientists outside of Ph.D.-granting, research institutions. These awards are supported entirely by Association general revenues - that is, by member dues-as one of the many facets of the Association's commitment to assuring scholarly opportunities for all.

APSA Research Support Awards are merit-based and this year include studies of the suffragists and the idea of women's political leadership, the oversight of the CIA in $1947-70$, argument in agenda transformation on the Supreme Court, partisanship and vote decision in the 1992 Presidential election, gender politics, and nuclear and hightechnology conventional weapons. The committee received 32 proposals.

The Research Support Committee is chaired by John Sprague, Washington University, and includes Charles W. Harris, Howard University; Margaret Karns, University of Dayton; Kathleen Knight, University of Houston; Stanley Rothman, Smith College; and
Karen O'Connor, Emory University.

The grant recipients are David $\mathrm{M}$. Barrett, Villanova University, "Senator Richard Russell and Congressional Oversight of the Central Intelligence Agency, 1947-1970"; Barbara C. Burrell, University of Wisconsin-Extension, "Connections: the Suffragists and the Idea of Womens Political Leadership"; Paula M. Fleming, California State University, "Power vs Frame: When Do States Take Risks?"; Katy J. Harriger, Wake Forest University, "The Role of Argument in Agenda Transformation on the Supreme Court"; James G. Leibert, Dickinson State University, "A Multivalued Examination of Parisanship and Vote Decision in the 1992 Presidential Election"; Amy G. Mazur, Indiana UniversityPurdue, "Comparative State Feminism: the Case of France"; Gary Prevost, St Johns University, “Social Movements and the Future of Spanish Social Democracy"; Mark J. Rozell, Mary Washington College, "The Christian Right in the Republican Party: Holy Alliance or Marriage of Convenience"; Anne Sisson Runyan, SUNY-Potsdam, "Gender Politics and the New World Order: An Examination of Feminist Responses to the European Community and the North American Free Trade AgreementInternational Feminism, Feminist Internationalism, or Feminist Internationalization"; George E. Shambaugh, Smith College, "Dominance, Dependence and Political Power: Controling Nuclear and High Technology Conventional Weapons Proliferation in the PostCold War Era"; Robert R. Thompson, Beaver College, “A Bulldog Among Spaniels. John Quincy Adams and the Genesis of RussianAmerican Relations, 1809-1814"; Luann K. Troxel, Smith College, "Women and Political Power in the New East Europe: Is There a Difference"; Craig M. Wheeland, Villanova University, "Council Evaluation of the City Manager's

Performance."

If you would like more information on APSA's research grants or have suggestions for the committee, please contact Michael Brint- 